\title{
OPEN Author Correction: A normalized template matching method for improving spike detection in extracellular voltage recordings
}

Keven J. Laboy-Juárez, Seoiyoung Ahn \& Daniel E. Feldman

Correction to: Scientific Reports https://doi.org/10.1038/s41598-019-48456-y, published online 19 August 2019

The original version of this Article contained an error in Affiliation 1, which was incorrectly given as:

'Depatment of Molecular and Cellular Biology and Helen Wills Neuroscience Institute, University of California Berkeley, Berkeley, CA, 94720, USA'

The correct affiliation is listed below:

'Department of Molecular and Cell Biology and Helen Wills Neuroscience Institute, University of California Berkeley, Berkeley, CA, 94720, USA'

This error has now been corrected in the HTML and PDF versions of the Article.

(c) Open Access This article is licensed under a Creative Commons Attribution 4.0 International License, which permits use, sharing, adaptation, distribution and reproduction in any medium or format, as long as you give appropriate credit to the original author(s) and the source, provide a link to the Creative Commons license, and indicate if changes were made. The images or other third party material in this article are included in the article's Creative Commons license, unless indicated otherwise in a credit line to the material. If material is not included in the article's Creative Commons license and your intended use is not permitted by statutory regulation or exceeds the permitted use, you will need to obtain permission directly from the copyright holder. To view a copy of this license, visit http://creativecommons.org/licenses/by/4.0/.

(c) The Author(s) 2019 